\section{Visión Electrónica Más que un estado sólido \\ https://doi.org/10.14483/issn.2248-4728}

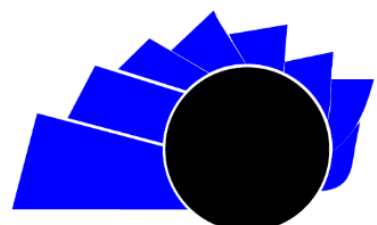

VISIÓN ELECTRÓNICA

\title{
Smart cities in collaboration with the internet of things
}

\author{
Ciudades inteligentes en colaboración con internet de las cosas
}

Ricardo Alirio González-Bustamante (D) ${ }^{1}$, Roberto Ferro-Escobar (D) ${ }^{2}$, Harold Vacca-González (iD 3

\begin{tabular}{l}
\hline INFORMACIÓN DEL ARTÍCULO \\
\hline Historia del artículo: \\
Enviado: 11/07/2020 \\
Recibido: 19/07/2020 \\
Aceptado: 13/09/2020 \\
\hline
\end{tabular}

Keywords:

Information and Communications

Technology

Internet of things

ICT

Smart cities

\section{ABSTRACT}

The use of the Internet has Reached a point in the world in Which it has become essential in everyday life, the need to Have information at hand in the shortest possible time has generated a technological revolution That incurs the constant connection to this tool, from our Personal life to the same objects That we use in daily life, creating a need to check what surrounds us to Improve our quality of life, reason for the birth of the Internet of Things (IoT, for acronym in English), as well as the convergence of our environment through the creation with Technology of smart cities (Smart City in English). In view of the above, this article addresses concepts about the future of smart cities in collaboration with the Internet of things, the advantages and Disadvantages of these, their comparison, reception, adaptability.

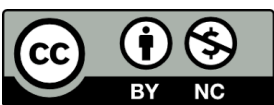

Palabras clave:

Tecnología de la Información y las Comunicaciones Internet de las Cosas TIC

Ciudades Inteligentes

\section{RESUMEN}

El uso de Internet ha llegado a un punto en el mundo en el que se ha vuelto esencial en la vida cotidiana, la necesidad de tener información a la mano en el menor tiempo posible ha generado una revolución tecnológica que incurre en la conexión constante a Internet, creando la necesidad de verificar lo que nos rodea para mejorar nuestra calidad de vida, razón por la cual nace Internet de las cosas (IoT, por sus siglas en inglés), también como la convergencia de nuestro entorno a través de la creación con de ciudades inteligentes (Smart City en inglés). En vista de lo anterior, este artículo aborda conceptos sobre el futuro de las ciudades inteligentes en colaboración con Internet de las Cosas, las ventajas y desventajas de estas, su comparación, recepción, adaptabilidad.

\footnotetext{
1 BSc. In Electronic Engineering, Universidad Distrital Francisco José de Caldas, Colombia. MSc. In Information Science, Universidad Distrital Francisco José de Caldas, Colombia. Current position: Professor at Fundación Autónoma de Colombia, Colombia. E-mail: gonzalez.ricardo@fuac.edu.co

${ }^{2} \mathrm{PhD}$. in Computer Engineering, Universidad Pontificia de Salamanca, Spain. MSc. in Teleinformatics, Universidad Distrital Francisco José de Caldas, Colombia. E-mail: rferro@udistrital.edu.co

${ }^{3}$ BSc. In Licensed in Mathematics, Universidad Distrital Francisco José de Caldas, Bogotá Colombia. MSc. in Mathematics Applied. Current position: Professor at Universidad Distrital Francisco José de Caldas, Colombia. E-mailः hvacca@udistrital.edu.co
} 


\section{Introduction}

The Internet boom was one of the catalysts to condense the massive development of devices that allow the constant connection with the environment and in turn transmit the information to the user so that it can gain control over the things around him, so as concepts as the internet of things have achieved a significant increase, reaching households in major cities improving the environment entering the scene smart cities [1] [2].

The first part of this article will focus on the pair, the internet of things and smart cities, with different approaches to publicize the joint work that they have achieved subtly with an indirect but profound relationship, their advantages and disadvantages facing the most important points of view of their use, have been coupled watching all these features in everyday life, both personal, family, and urban [3] [4].

The second part will focus on the impacts that has achieved technological development and advancement of interconnectivity and interoperability who have won the objects with people through the internet at a social level, from economic fields, grazing a little cultural. The latter cover a major issue and the current academic approach and the expansion of new professional possibilities, not only technically but with a global vision of the effect they can have those with expertise in related areas of technology research, in today's world [5] [6].

Finally, we show how these concepts are now positioned globally through advancements in devices that assist in project development.

\section{Construction Features Interaction in the Internet of Things and Smart Cities}

To understand the convergence of ideals between the Internet of things and smart cities is necessary to display different views regarding their development and implementation, why should an overview of the minimum aspects that shape. To do this the most important aspects and features that take a base of the subject matter from these fields will be displayed [7] [8].

\subsection{Advantages}

The verification process is performed by a personal and manually display, but with an interconnected system failure immediately appear on screen, allowing the most efficient repair monitoring your state to proactively plan maintenance and minimize these failures, and this one of its greatest benefits when opting for these advances [4][9]. The internet of things, has allowed the integration of people, objects, data and processes, four fundamental pillars in the development and evolution of our technological infrastructure through interoperability and interconnection of various fields in the world [10] [11].

Also, through its implementation is achieved savings in time monitoring, managing and monitoring real-time; data analysis is fast thanks to its ease of making correct decisions avoiding innumerable failures that occur in supervisions and personal efforts; allowing better management of resources economically [12] [13].

In smart cities, by screening a larger infrastructure with respect to monitoring and managing processes, see I is reflected optimum performance and facilitate the integration of processes in public administration, generating common procedures that increase efficiency; optimizing the allocation of resources and reducing unnecessary expenses; producing performance indicators that are useful to measure, compare and improve public policy [14] [15], see Figure 1.

Figure 1. Technique for Interconnecting Technologies.
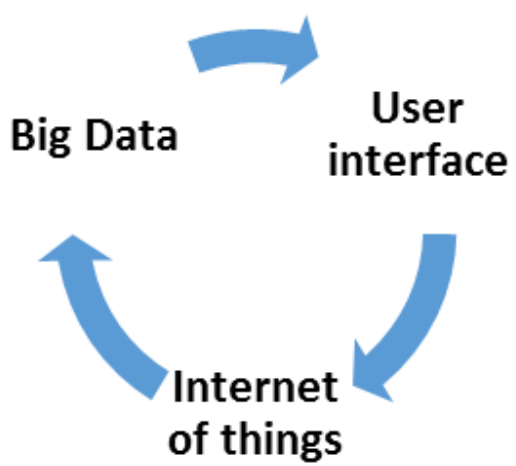

Source: own.

\subsection{Disadvantages}

The internet of things has a strong focus between the interconnection of everything that surrounds people through sensors and actuators, improving the quality of life of citizens [16].

Security and privacy are a big problem with the Internet of things, being one of the most questioned and debated regarding its use and mass deployment issues. All security risks become risk [17]. 


\subsection{Comparison}

Convergence between the Internet of things and smart cities is the Internet, being the network of networks, which allows to interconnect all devices achieving interoperability and better process management

Another aspect that achieves this convergence is handling sensors, allowing quantify each of the measurable variables around us, but going on a domestic scale, such as gas meters, or temperature at a metropolitan scale, as you can be the measurement of electricity consumption in electric lighting, motion detection traffic [18]. Reason you should have a minimum understanding of these technologies taking into account its scope [19].

It is a smart city one that puts people at the center of development, incorporating information and communications technology (ICT for short) in urban management, using these as tools to stimulate the formation of an efficient government processes include collaborative planning and citizen participation, and being the Internet of things a concept that refers to the digital networking of everyday devices to the Internet. The relationship that these two regarding interconnectivity through networks and the Internet and the need for troubleshooting and improvement, with different perspectives on the scale of operation and a social approach that enables seamless operation from a technical point of view, minimum and responsible manner [20] [21].

\subsection{Planning and Development}

The transformation of a city into a metropolis intelligent involves active participation of governmental and social actors. Today the big cities combine the best of their planning systems technology information and art communications that provide citizens with access to multiple platforms across different devices, allowing technological integration and approach to an interconnection of each aspect of life, an approach the massive internet things, smart cities [22] [23] [24]. In this context, implementations of technologies aimed at generating large volumes of data must be managed by qualified personnel, which is why it is imperative to empower institutions that manage these processes to manage information effectively [25] [26].

Moreover, buildings are the building blocks from which cities are made. Consume around $40 \%$ of all global energy and an estimated further $50 \%$ of all that consumption is not efficient. In the case of the US, buildings consume reach $70 \%$ of all electricity, of which $50 \%$ is wasted, and in the same way squander $50 \%$ of their water. Against this background it is reasonable to apply this technology to improve management is one of the most prominent areas of smart cities [27] [28] [29].

However, cities in Latin America and in Colombia, where it has already been significant attempts have not yet made the leap in masse. To do this, "Colombian regulations, and in many Latin American countries should encourage these technological changes in administrations, since the resources freed by reducing power consumption can be reinvested in complex social projects to quantify [30] [31]. The key is to form a single network. This process allows the automation of the operation of the lighting to overcome the challenges of traditional analog or lighting, as well as many other processes can be improved and more efficient.

\subsection{Security and data management}

Each time, the cities are leading a greater number of policing projects such as installing cameras at strategic points of the metropolis that are activated in case of emergency, reinforcing the security of the population, as well as systems for measuring and improving mobility the city by installing technology platforms that give results in real time for decision-making [32] [33] [34]. Management data generated in an intelligent city through thousands of connected sensors is huge and confidential. Nobody came up with the security requirement would be critical [35].

Figure 2. IoT System in Smart City [37].

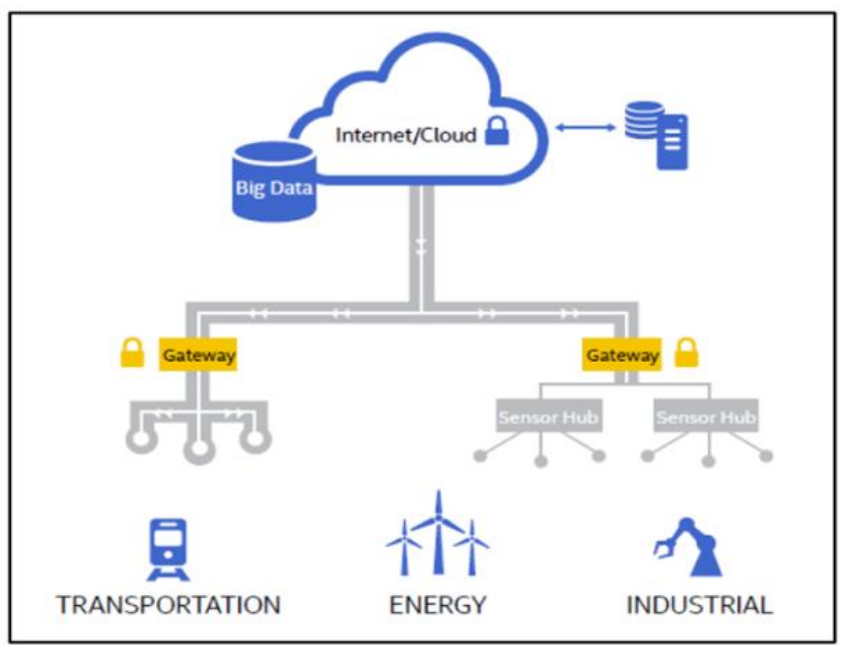


Now designers and developers, applications programs such as electronic devices are more aware of the situation and the security issue is beginning to be addressed holistically in all components. But still they appear applications with vulnerabilities and apparatus whose communication protocol is not secure [36].

To solve these problems working on techniques for automatic evaluation, if possible, problems are detected and can be corrected in time, see Figure 2. They are also improving detection techniques to incorporate dynamic response mechanisms unknown events.

\subsection{Adaptability and sustainability}

Adaptability to discuss a pre-service concept of intelligent cities, in this context necessary to refer to services that have to do with governance in all matters relating to transparency and participation in decisionmaking; increasing educational programs on the proper use of technologies are included, in order to boost its ownership among communities through inclusive systems. Later these initiatives evolve and become regulations, regulations, laws and policies of technological development within a legal framework promoted a radical change in cities [38].

Among the most common uses include sites for conducting surveys and polls, as well as social networks that promote communication and association of different stakeholders, creating an integration and constant relationship with the technologies proposed [39].

There are two types of approaches to a smart city. One is from the city inward in the sense of how we can gain efficiencies in network services of general interest. And there is another, as is the case of Santander, seeing it as an engine or a tool in strategic planning for change [40]. to promote an integrated and sustainable development, cities become more innovative, competitive and attractive.

\section{Current and future vision}

Currently, the growth and acceptance of new technologies has managed to become indispensable in many aspects of everyday life, and imperceptible by the massification of these in multiple business sectors, government, and as open to the public environments and elsewhere in which people spend most of their time [41]. It is undeniable progress that has been achieved through this technological development, which involves responsible management of this technology [42].

\subsection{Technological Influence}

More than half of the world population lives in cities with the expectation that manages United Nations notes that $70 \%$ of human beings will live in urban centers by 2050. This body... "Warns that the increase in the population of cities it can become a real problem, unless it is able to maintain harmony among the spatial, social and environmental aspects of localities and among its inhabitants." [43]

The influence of these consequences poses a challenge. In turn, seeing new business opportunities that are presented, large company's information, computer and electronics such leverage social situation for a new consumer market. The term smart cities, where technology plays an important factor sponsors [44]. Infrastructure systems are changing due to globalization and market demand a smarter approach involving urban planning buildings, transport and energy systems, to ensure the protection of persons and property. According to Gartner it estimates that by 2020, there will be around 9,700 million objects connected to meet the needs of the inhabitants of smart cities [32].

Technology is merely a tool for prevention, protection, coordination and control, which generates information to make better decisions in the hands of a competent team. Innovation is not just about electronic devices but human talent behind and empowering the authorities, and the commitment of citizens, because otherwise they will result in huge investments without specific impacts [45]

\subsection{Socio-economic background}

The focus of the ICT Forum for safe cities organized by Publications week, was focused on World Bank figures that said the rapid growth of the global population means that by $203060 \%$ of the world's people will live in urban areas. For this reason, accelerated urbanization and migration processes that generate major challenges around transport systems, utility networks and existing emergencies, create the need to improve security in cities through the use of technological tools [46].

In recent years, local governments have invested in systems to ensure safe cities more efficient social and economic environments. "Build centralized command centers facilitate processing and monitoring of events in real time, which helps to prevent, manage and mitigate its impact. Given that the territories have limited 
resources, technological tools become a key factor for decision-making, thus optimizing resources and generate greater sense of security to people, "said the executive of Huawei [47]. It is in this way ICT sector companies become strategic partners to develop projects that require the support and infrastructure design suitable for building smart cities [48].

\subsection{Cultural Impact}

Rapid and unplanned growth of cities in Latin America has generated a number of challenges that cannot be solved in a traditional way: insecurity, vulnerability to climate change and natural disasters, the increasing number of vehicles on urban roads the increase in energy consumption, environmental pollution, water and waste management, the need for greater citizen participation and greater efficiency in services among others [49].

Likewise, the development of safer cities generates a greater sense of belonging to citizens and promotes the competitiveness of cities. "To ensure the successful implementation of safe cities is necessary to articulate a vision and a mission, align governance structures, define a funding model, develop ecosystems of interest and integrating solutions into a communication strategy and appropriation becomes all citizens protagonists of the transformation "[50]

\section{Current Advances}

Implementation of the Internet of things has allowed the interconnection and resource management is classified as "smart". Term that was coined by the media and marketing to sell innovative products that would tell consumers understand the utility that these have in everyday life for any area in which they are used.

\subsection{Models implemented}

Mobility is one of the key points to be addressed in a smart city, because the conflicts that arise at the social, environmental, and traffic, so the implementation of electric vehicles in cities and other elements motor, and respective positions of public and private charging, also called eMobility, is a clear example Tesla cars, under the command of Elon Musk [51].

Another important point to deal with smart cities are smart interconnected networks, also called Smart Grids, which have a circulation in both directions of data between the service center or control center and the user who inhabits city, where we already have they framed the importance of massive data traffic that a smart city can generate models are needed that these data are regulated in the best way [52].

Intelligent buildings in a city, have to be ingenious and more efficient energy. Buildings automation and other electronics that are environmentally environment and production systems with integrated energy, the implemented model is known as Smart Building and the surrounding environment every aspect of them manage.

Figure 3. Illustration of the fundamentals of an intelligent city [53].

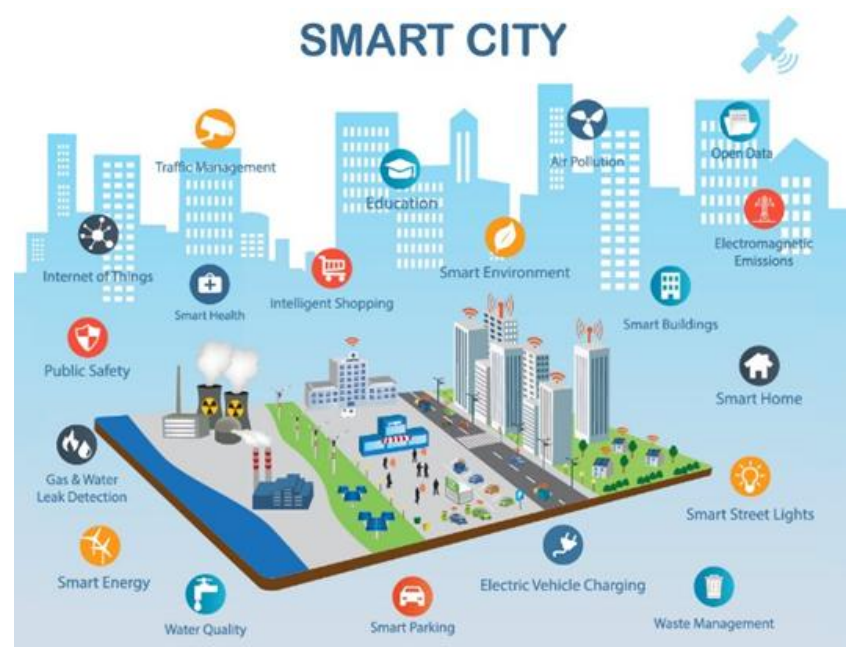

Smart measurements in public services in consumer spending enable better data spending for energy example, see Figure 3, each user by means of counters tele where readings remotely and in real time, which is being implemented much in are made electrical services and is booming to provide better services, also called Smart Metering [54].

Smart sensors will have the function to summarize each and every one of the information needed to make the smarter city. They are essential to sustain connectivity and information, and make each part subsystem to perform its function [55].

Citizens and residents are undoubtedly the essential part of a city, while without their active participation is not possible to make these ideas, so models like the Smart Citizen, achieve a stake in keeping the technological advances of an intelligent city, improving fundamental aspects of communication and participation in decision-making [56]. 


\subsection{Devices for the development of the Internet of Things}

Many of these devices are readily available and allow anyone with minimal technical expertise in electronics and design from scratch a project schedule, reason which must be taken into account.

\subsubsection{Arduino}

Arduino is a prototype platform based on open source easy to use hardware and software. Arduino boards are able to read inputs - a light sensor, a finger on a button or a Twitter message - and turn it into an output activating a motor, light a LED, publish something online. You can tell your board what to do by sending a set of instructions for the microcontroller on the board. For this the Arduino programming language (based on Wiring) and the Arduino software (IDE) based on Processing is used, Figure 4.

Arduino software is released as open source tools, available for extension by experienced programmers. The language can be expanded through $\mathrm{C}++$ libraries, and people wanting to understand the technical details can make the leap from Arduino to the AVR C programming language in which it is based. Similarly, you can add AVR-C code directly into your Arduino programs if you want (Arduino).

Figure 4. Arduino [57].

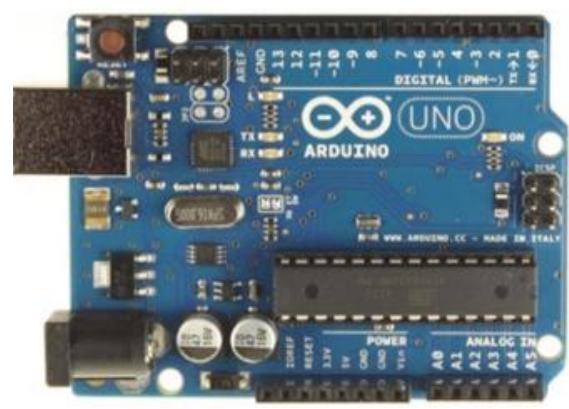

\subsubsection{Raspberry Pi}

This device is a computer small plate, computer single board or computer single board (SBC) whose price is affordable for low cost, which is developed in the UK by the Raspberry Pi Foundation, with the aim of stimulating teaching of computer science. The Raspberry Pi mostly used operating systems based on the Linux kernel. Raspbian a Debian-derived distribution that is optimized for Raspberry $\mathrm{Pi}$ hardware, see Figure 5.
Figure 5. Plate Raspberry Pi [58].

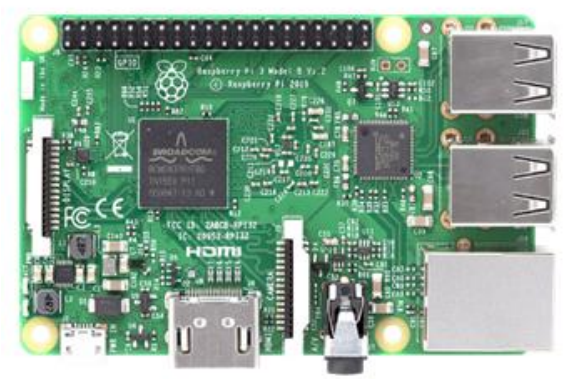

\subsubsection{Portable Wireless Router $N$}

Laptop that is able to share a $3 \mathrm{G} / 4 \mathrm{G}$ mobile connection, compatible with more than 120 USB modems $3 \mathrm{G} / 4 \mathrm{G}$

LTE / HSPA + / UMTS / EVDO operating tested. Design size for travel, small enough and able to incorporate it into smaller sites such as the reading system platforms, it allows $3 \mathrm{G} / 4 \mathrm{G}$ mobile connection anywhere $3 \mathrm{G} / 4 \mathrm{G}$ coverage is available, has a wireless speed up to $150 \mathrm{Mbps}$, has other for different situations: $3 \mathrm{G}$ router / 4G, WISP client router and AP. Backup Strategy recovery system 3G / 4G / WAN, the TLMR3020 data can provide a stable Internet connection.

\subsubsection{Wi-Fi module ESP8266}

This small module allows microcontrollers to connect to a Wi-Fi network and perform simple TCP / IP connections using Hayes commands type. However, at that time there were almost no English documentation on the chip and accepting commands, see Figure 6.

\section{Figure 6. Wi-Fi module ESP8266 [59]}

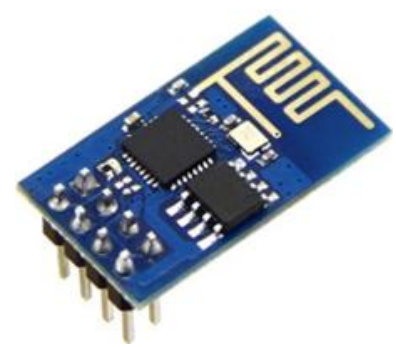

\subsubsection{ACS720 current sensor}

The current sensor ACS712 is an economical solution to measure current, internally works with a Hall effect sensor detects the magnetic field produced by the 
induction current in the line being measured. The sensor gives us output voltage proportional to the current, depending on the application can use the ACS712-05A, ACS712-20A or ACS712-30A to ranges of 5, 20 or 30 amps respectively, see Figure 7 .

\section{Figure 7. Current Sensor ACS720 [60].}

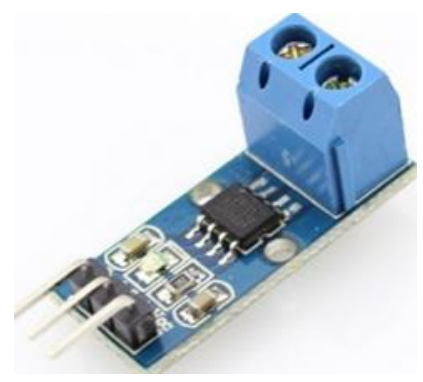

\subsubsection{Sound sensor LM393}

It is a small sensor based on the LM393 and a sensitive microphone, see Figure 8. For automation projects and automation works perfect, you can control lights, alarms, even a small sound follower robot

It has a potentiometer so you can set the volume without problem. Its features are: $5 \mathrm{~V}, 3$-pin interface (Arduino).

Figure 8. Sound sensor LM393 [60].

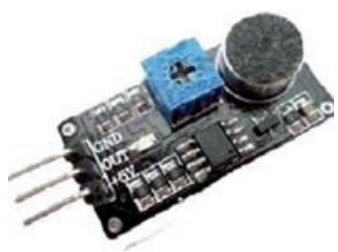

\subsubsection{Air quality sensor $M Q-135$}

This module is capable of measuring air quality in buildings / houses can detect the presence of: NH3, NOx, alcohol, benzene, smoke, CO2, see Figure 9.

Figure 9. Air quality sensor MQ-135 [61].

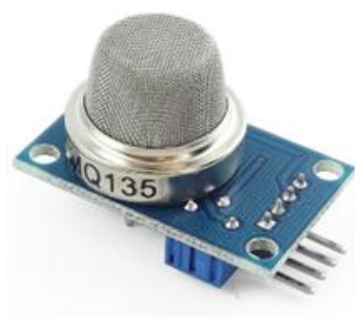

\subsubsection{DHT11 sensor (humidity and temperature)}

This sensor is characterized by calibrated digital signal which ensures high quality and reliability over time, since it contains a microcontroller integrated 8 bits. It consists of two resistive sensors (NTC and humidity). It has excellent quality and rapid response measures. It can measure moisture range between $20 \%$ - approx. 95\% and temperature between $0{ }^{\circ} \mathrm{C}$ range $50 \mathrm{C}$.

\section{Conclusions}

The approach used in the paradigm of the Internet of Things (IoT), has managed to change direction following the technology until recently only, in which the domain of personal systems to see very limited the possibilities this would have on the future. However, with the Io $\mathrm{T}$ it has been able to envision a future in which both passive devices and active will be part of our lives and in many cases so we will not be aware of it.

The IoT has been used with great potential in almost every aspect of human development, from helping us in our homes to complex systems of medical, police or against natural disasters alert. Cities have not escaped this potential, and that is how, in many parts of the world, have been developed such systems fail to contextualize the city allowing its people to meet and make decisions firsthand aspect of everyday character to a while ago could have no interaction as they were, for example, traffic control, verification of environmental parameters, alerts, display security and countless other aspects, which thanks to technology are managing to be part of life everyday people.

This project was based on the application of this paradigm for monitoring the intensity of noise and air quality in urban areas. Using this approach it was possible to develop a device capable of collecting and measuring these parameters, process and through a web application to make available to the public with this information in an updated and therefore with immediate knowledge of aspects such as pollutants of various types, auditory interference and others that have been shown can affect health and generate low productivity of people. Having knowledge of these values will allow taking, for example, to avoid or prepare decisions should address these various factors of environmental pollution.

The different approaches of an intelligent city were reviewed and developed a general tour for its definition, 
characteristics and architecture, seeking to understand its operation and its interaction with the internet of things.

\section{References}

[1] Fundación COTEC para la Innovación, "Internet de las cosas: análisis de oferta educativa y la demanda empresarial en España”, 2017. [Online]. Available at: http://informecotec.es/media/informe_IOT_Cotec2 017.pdf.pdf

[2] F. Cirillo, D. Gómez, L. Diez, I. Elicegui Maestro, T. B. Gilbert, R. Akhavan, "Smart City IoT Services Creation Through Large-Scale Collaboration", IEEE Internet of Things Journal, vol. 7, no. 6, pp. 5267-5275, June 2020. https://doi.org/10.1109/JIOT.2020.2978770

[3] S. Javaid, A. Sufian, S. Pervaiz, M. Tanveer, "Smart Traffic Management System Using Internet of Things", 20th International Conference on Advanced Communication Technology (ICACT), pp. 393-398, 2018. https://doi.org/10.23919/ICACT.2018.8323770

[4] F. Montori, L. Bedogni and L. Bononi, "A Collaborative Internet of Things Architecture for Smart Cities and Environmental Monitoring", IEEE Internet of Things Journal, vol. 5, no. 2, pp. 592-605, April 2018. https://doi.org/10.1109/JIOT.2017.2720855

[5] D. Evans, "The Internet of Things: How the Next Evolution of the Internet Is Changing Everything", 2011. [Online]. Available at: https://www.cisco.com/c/dam/global/es_mx/solution s/executive/assets/pdf/internet-of-things-iotibsg.pdf

[6] A. Rucinski, R. Garbos, J. Jeffords, S. Chowdbury, "Disruptive innovation in the era of global cybersociety: With focus on smart city efforts", 9th IEEE International Conference on Intelligent Data Acquisition and Advanced Computing Systems: Technology and Applications (IDAACS), pp. 11021104, 2017. https://doi.org/10.1109/IDAACS.2017.8095256

[7] E. Sosa, D. Godoy, R. Neis, G. Motta, R. Luft, D. Sosa, H. Bareiro, P. Quiñones, "Internet del Futuro y Ciudades Inteligentes", 2013. [Online]. Available at: http://sedici.unlp.edu.ar/bitstream/handle/10915/2 7086/03-Internet+del+Futuro.pdf?sequence $=1$

[8] C. Shen, K. Zhang and K. Long, "Research on Hainan Trusted Digital Infrastructure Construction Framework", 29th Wireless and Optical Communications Conference (WOCC), pp. $1-5$, 2020. https://doi.org/10.1109/WOCC48579.2020.9114945

[9] M. K. Patra, "An architecture model for smart city using Cognitive Internet of Things (CIoT)", Second International Conference on Electrical, Computer and Communication Technologies (ICECCT), pp. 16 , 2017. https://doi.org/10.1109/ICECCT.2017.8117893

[10] Colegio Oficial de Ingenieros de Telecomunicación, "Informe sobre La tendencia inteligente de las ciudades en España", 2018. [Online]. Available at: https://www.coit.es/sites/default/files/informes/pdf/ 2018-01-

30_coit_grupo_scsr_informe_tendencia_smart_ver sion_final.pdf

[11] F. Alkhabbas, R. Spalazzese, P. Davidsson, "Architecting Emergent Configurations in the Internet of Things", IEEE International Conference on Software Architecture (ICSA), Gothenburg, pp. 221-224 2017. https://doi.org/10.1109/ICSA.2017.37

[12] H. Merry, "Population increase and the smart city - Internet of Things blog", pp. 187-193, 2017. [Online]. Available at: https://www.ibm.com/blogs/internet-ofthings/increased-population-smart-city/

[13] J. Hribar, L. DaSilva, "Utilising Correlated Information to Improve the Sustainability of Internet of Things Devices", IEEE 5th World Forum on Internet of Things (WF-IoT), Limerick, Ireland, pp. $\quad 805-808$, https://doi.org/10.1109/WF-IoT.2019.8767256

[14] S. Igder, S. Bhattacharya, J. Elmirghani, "Energy efficient fog servers for Internet of Things Information Piece Delivery (IoTIPD) in a smart city vehicular environment", International Conference on Next Generation Mobile Applications, Services, and Technologies, pp. 99-104, 2016. https://doi.org/10.1109/NGMAST.2016.17 
[15] S. Yaqoob, A. Ullah, M. Akbar, M. Imran, M. Guizani, "Fog-assisted Congestion Avoidance Scheme for Internet of Vehicles", 14th International Wireless Communications \& Mobile Computing Conference (IWCMC), Limassol, pp. 618-622, https://doi.org/10.1109/IWCMC.2018.8450402

[16] P. Rizwan, K. Suresh, M. Babu, "Real-time smart traffic management system for smart cities by using Internet of Things and big data", International Conference on Emerging Technological Trends (ICETT), pp. 1-7, 2016. https://doi.org/10.1109/ICETT.2016.7873660

[17] D. C. Bogatinoska, R. Malekian, J. Trengoska, W. Nyako, "Advanced sensing and internet of things in smart cities", 39th International Convention on Information and Communication Technology, Electronics and Microelectronics, MIPRO Proceedings, pp. 632-637, 2016. https://doi.org/10.1109/MIPRO.2016.7522218

[18] Ernst and Young, "Libro Blanco Smart Cities", 2012. [Online]. Available at: http://www.innopro.es/pdfs/libro_blanco_smart_cit ies.pdf

[19] S. Trabuchi, "Cantones Sostenibles para la Costa Rica del siglo XXI", 2016. [Online]. Available at: https://www.itu.int/en/ITU-D/RegionalPresence/Americas/Documents/EVENTS/2016/155 57-CR/15557-4-1.pdf

[20] O. G. Fuentes, J. F. Pérez, "Implementación de un sistema de seguridad independiente y automatización de una residencia por medio del internet de las cosas", IEEE Central America and Panama Student Conference (CONESCAPAN), 2017.

https://doi.org/10.1109/CONESCAPAN.2017.8277 600

[21] O. B. Mora, R. Rivera, V. M. Larios, J. R. BeltránRamírez, R. Maciel. A. Ochoa, "A Use Case in Cybersecurity based in Blockchain to deal with the security and privacy of citizens and Smart Cities Cyberinfrastructures", IEEE International Smart Cities Conference (ISC2), pp. 1-4, 2018. https://doi.org/10.1109/ISC2.2018.8656694

[22] A. M. Alberti, G. Scarpioni, V. Magalhaes, A. Cerqueira, J. Rodrigues, R. Righi, "Advancing NovaGenesis Architecture Towards Future
Internet of Things", IEEE Internet of Things Journal, vol. 6, no. 1, pp. 215-229, 2017. https://doi.org/10.1109/JIOT.2017.2723953

[23] S. Koutra, V. Becue, C. S. Ioakimidis, "A Multiscalar Approach for 'Smart City' Planning", IEEE International Smart Cities Conference (ISC2), pp. $1-7, \quad 2018$. https://doi.org/10.1109/ISC2.2018.8656889

[24] P. Dias, J. Rodrigues, A. Aguiar and G. David, "Planning and managing data for Smart Cities: an application profile for the UrbanSense project", IEEE International Smart Cities Conference (ISC2), pp. 1 1-2, 2018. https://doi.org/10.1109/ISC2.2018.8656835

[25] Ministerio de Tecnologías de la Información y las Comunicaciones, "Convocatoria vive digital regional 2015", 2015. [online]. Available at: http://www.colciencias.gov.co/sites/default/files/upl oad/convocatoria/Anexo1_2.pdf

[26] J. C. Najar-Pacheco, J. A. Bohada-Jaime, W. Y. Rojas-Moreno, "Vulnerabilidades en el internet de las cosas", Visión Electrónica, vol. 13, no. 2, pp. 312-321, 2019. https://doi.org/10.14483/22484728.15163

[27] B. Ahlgren, M. Hidell, E. Ngai, "Internet of Things for Smart Cities: Interoperability and Open Data", IEEE Internet Computing, vol. 20, no. 6, pp. 52-56, 2016. https://doi.org/10.1109/MIC.2016.124

[28] J. An, F. Gall, J. Kim, J. Yun, J. Hwang, M. Bauer, M. Zhao, J. Song, "Toward Global IoT-Enabled Smart Cities Interworking Using Adaptive Semantic Adapter", IEEE Internet of Things Journal, vol. 6, no. 3, pp. 5753-5765, 2019. https://doi.org/10.1109/JIOT.2019.2905275

[29] M. A. Barrera Pérez, N. Y. Serrato Losada, E. Rojas Sánchez, G. Mancilla Gaona, "Estado del arte en redes definidas por software (SDN)", Visión Electrónica, vol. 13, no. 1, pp. 178-194, 2019. https://doi.org/10.14483/22484728.14424

[30] V. Govindraj, M. Sathiyanarayanan, B. Abubakar, "Customary homes to smart homes using Internet of Things (IoT) and mobile application", International Conference On Smart Technologies for Smart Nation (SmartTechCon), pp. 1059-1063, 2017. 
https://doi.org/10.1109/SmartTechCon.2017.83585 32

[31] L. Jalal, M. Murroni, V. Popescu, "Experimental setup for IoT - Based multi sensorial media", Baltic URSI Symposium (URSI), Poznan, pp. 80-84, 2018. https://doi.org/10.23919/URSI.2018.8406735

[32] F. Espiga, G. Garai, "Hacia un futuro inteligente, 5 claves para diseñar las Smart cities". [Online]. Available at: https://www.tecnalia.com/images/stories/Eventos/I nforme_Futuro_Ciudades_TECNALIA.pdf

[33] S. Ghosh, "Smart homes: Architectural and engineering design imperatives for smart city building codes", Technologies for Smart-City Energy Security and Power (ICSESP), Bhubaneswar, pp. 1-4, 2018. https://doi.org/10.1109/ICSESP.2018.8376676

[34] N. Villanueva-Rosales, L. Garnica-Chavira, V. Larios, L. Gómez, E. Aceves, "Semantic-enhanced living labs for better interoperability of smart cities solutions", IEEE International Smart Cities Conference (ISC2), Trento, pp. 1-2, 2016. https://doi.org/10.1109/ISC2.2016.7580775

[35] Smart City, "What is a smart city?". [Online]. Available at: https://www.wien.gv.at/stadtentwicklung/studien/ pdf/b008403j.pdf

[36] W. Ejaz, M. Naeem, A. Shahid, A. Anpalagan, M. Jo, "Efficient Energy Management for Internet of Things in Smart Cities", IEEE Communications Magazine, vol. 55, no. 1, pp. 84-91, 2017. https://doi.org/10.1109/MCOM.2017.1600218CM

[37] R. R. Harmon, E. G. Castro-Leon, S. Bhide, "Smart cities and the Internet of Things", Portland International Conference on Management of Engineering and Technology (PICMET), pp. 485494 , 2015. https://doi.org/10.1109/PICMET.2015.7273174

[38] J. Ramirez, "Performance analysis of communication protocols for Internet of Things platforms", IEEE Colombian Conference on Communications and Computing (COLCOM), 2017.

https://doi.org/10.1109/ColComCon.2017.8088198
[39] K. Rose, S. Eldridge, L. Chapin, "La internet de las cosas- una breve reseña", 2015. [Online]. Available at: https://www.internetsociety.org/wpcontent/uploads/2017/09/report-InternetOfThings20160817-es-1.pdf

[40] O. O. Flores-Cortez, V. Rosa, "Monitoreo remoto usando internet de las cosas", IEEE 37th Central America and Panama Convention (CONCAPAN XXXVII), 2017. https://doi.org/10.1109/CONCAPAN.2017.8278466

[41] Ces, "Smart Cities Experiencing Explosive Growth". [Online]. Available at: https://www.ces.tech/CES/media/pdfs/smart-citiessales.pdf

[42] Fundación Telefónica, "Smart Cities: un primer paso hacia la Internet de las cosas", 2011. [Online]. Available at: https://www.socinfo.es/contenido/seminarios/1404s martcities6/01-TelefonicaSMART_CITIES2011.pdf

[43] J. F. Velásquez, J. C. Viviescaz, "El internet de las cosas como alternativa de control al consumo de los recursos naturales en las ciudades", tesis, Universidad Uniminuto, Colombia, 2017.

[44] J. López, J. Chávez, A. Sánchez, "Modelado de una red de sensores y actuadores inalámbrica para aplicaciones en agricultura de precisión”, IEEE Mexican Humanitarian Technology Conference, MHTC, pp. 109-116, 2017. https://doi.org/10.1109/MHTC.2017.7926210

[45] M. Bouskela, M. Casseb, S. Bassi, C. Luca, M. Facchina, "La ruta hacia las Smart Cities Migrando de una gestión tradicional a la ciudad inteligente". [Online]. Available at: https://publications.iadb.org/bitstream/handle/113 19/7743/La-ruta-hacia-las-smart-cities-Migrandode-una-gestion-tradicional-a-la-ciudadinteligente.pdf

[46] RedIRIS, "Internet del futuro: desarrollando entornos innovadores para los nuevos servicios online". [Online]. Available at: http://www.rediris.es/difusion/publicaciones/casos_ uso/mm/FI-Core.pdf

[47] Universidad Nacional de Colombia, "Ciudades Inteligentes ¿realidad o utopía?”, 2017. [Online]. Available 
https://www.institutodeestudiosurbanos.info/obser vatorio-de-gobierno-urbano/publicaciones-dedebates-urbanos/1412-debates-de-gobiernourbano-14/file

[48] Telefónica, "Smart Cities La transformación digital de las ciudades". [Online]. Available at: https://iot.telefonica.com/libroblanco-smartcities/media/libro-blanco-smart-cities-esp-2015.pdf

[49] N. Dlodlo, O. Gcaba, A. Smith, "Internet of things technologies in smart cities", 2016 IST-Africa Conference, $\quad$ IST-Africa 2016. https://doi.org/10.1109/ISTAFRICA.2016.7530575

[50] Y. Mehmood, F. Ahmad, I. Yaqoob, A. Adnane, M. Imran, S. Guizani, "Internet-of-Things-Based Smart Cities: Recent Advances and Challenges", IEEE Communications Magazine, vol. 55, no. 9, pp. 16-24,

2017. https://doi.org/10.1109/MCOM.2017.1600514

[51] A. López, "Ciudad inteligente y sostenible: hacia un modelo de innovación inclusiva", PAAKAT: revista de tecnología y sociedad, vol. 7, no. 13, 2018. https://doi.org/10.18381/Pk.a7n13.299

[52] Crcom, "Consulta sobre el Internet de las Cosas (IoT), 2016. [Online]. Available at: https://www.crcom.gov.co/recursos_user/2016/Acti vidades_regulatorias/PCA_IoT/com/Verizon.pdf

[53] B. N. Silva, M. Khan, C. Jung, J. Seo, D. Muhammad, J. Han, Y. Yoon, K. Han, "Urban planning and smart city decision management empowered by real-time data processing using big data analytics", Sensors, vol. 18, no. 9, pp. 6-12, 2018. https://doi.org/10.3390/s18092994

[54] M. Barrio, "Internet de las cosas", 2018. [Online]. Available at: https://www.editorialreus.es/static/pdf/primeraspa ginas_9788429020380_internetdelascosas.pdf
[55] M. E. Estavillo Flores, "Internet de las cosas: retos para su desarrollo", 2016. [Online]. Available at: http://www.ift.org.mx/sites/default/files/conocenos/ pleno/presentaciones/maria-elena-estavilloflores/comenoriotmeef160523.pdf

[56] A. Zanella, N. Bui, A. Castellani, L. Vangelista, M. Zorzi, "Internet of Things for Smart Cities", IEEE Internet of Things Journal, vol. 1, no. 1, pp. 22-32, 2014. https://doi.org/10.1109/JIOT.2014.2306328

[57] C. P. Millahual, "Arduino de cero a Experto", Buenos Aires, Argentina: Six ediciones, p. 29, 2017.

[58] A. Monteiro, M. de Oliveira, R. de Oliveira, T. da Silva, "Embedded application of convolutional neural networks on Raspberry Pi for SHM", Electronics Letters, vol. 54, no. 11, pp. 680-682, 2018. https://doi.org/10.1049/el.2018.0877

[59] R. S. Rosli, M. H. Habaebi, M. R. Islam, "Characteristic Analysis of Received Signal Strength Indicator from ESP8266 Wi-Fi Transceiver Module", 7th International Conference on Computer and Communication Engineering (ICCCE), pp. 504-507, 2018. https://doi.org/10.1109/ICCCE.2018.8539338

[60] K. Gayathri, "Implementation of Environment Parameters Monitoring in a Manufacturing Industry using IOT", 5th International Conference on Advanced Computing \& Communication Systems (ICACCS), Coimbatore, India, pp. 858862 ,

2019. https://doi.org/10.1109/ICACCS.2019.8728365

[61] M. Simić, G. M. Stojanović, L. Manjakkal, K. Zaraska, "Multi-sensor system for remote environmental (air and water) quality monitoring", 24th Telecommunications Forum (TELFOR), Belgrade, pp. 1-4, 2016. https://doi.org/10.1109/TELFOR.2016.7818711 